\title{
The Anti-inflammatory Activity of
} p-methoxycinnamic acid (PMCA)

in the Nanostructured lipid carrier

$$
\begin{aligned}
& \text { (NLC) system using } \\
& \text { combinations of solid lipid, }
\end{aligned}
$$

beeswax-oleum cacao and liquid

$$
\text { lipid, Virgin Coconut }
$$

Submission date: 16-Aug-2019 03:34PM (UTC+0800)

Submission ID: 1160576200

File name: 7_RJPT_12_8_2019.pdf (346.94K)

Word count: 5138

Character count: 25553 
ISSN 0974-3618 (Print) 0974-360X (Online) www.rjptonline.org

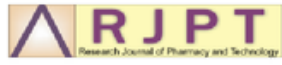

\title{
RESEARCH ARTICLE
}

\author{
The Anti-inflammatory Activity of $p$-methoxycinnamic acid (PMCA) in the \\ Nanostructured lipid carrier (NLC) system using combinations of solid \\ lipid, beeswax-oleum cacao and liquid lipid, Virgin Coconut oil (VCO) \\ Tristiana Erawati*, Dewi Melani Hariyadi, Noorma Rosita, Tutiek Purwanti \\ Department of Pharmaceutics Faculty of Pharmacy, Airlangga University, Surabaya, Indonesia \\ *Corresponding Author E-mail: era_ffua@yahoo.co.id, tristiana-e-m@ff.unair.ac.id
}

\begin{abstract}
:
Objective: The nanostructured lipid carrier (NLC) system used the combination of beeswax-oleum cacao and virgin coconut oil (VCO) in this study, it was the development of nanoemulsion (NE) and solid lipid nanoparticle (SLN) delivery systems, which are used as nano-carriers of $p$-methoxycinnamic acid (PMCA). PMCA a secunder metabolite of champheria galanga has antiinflamatory effect which is difficult to dissolve in water. Several combinations of solid lipids (beeswax-oleum cacao) and liquid lipids (VCO) were prepared, namely F I (60:40); F II (70:30); and F III (80:20) in the NLC system. Material and Method: The NLC-PMCA system was prepared by the high shear homogenization method, then characterized and subjected to antiinflammatory activity tests compared with nanoemulsion and solid lipid nanoparticle (SLN). The results of the research: The increasing concentration of VCO in the NLC-PMCA system resulted in lower viscosity, and greater entrapment efficiency, namely in the NLC-PMCA system with a combination of beeswax-oleum cacao and VCO of 60:40. NLC-PMCA with the combination of beeswax-oleum cacao and VCO of 60:40 (F I) has particle size $(236.00 \pm 17.15 \mathrm{~nm})$ smaller than SLN-PMCA $(665.60 \pm 72.59 \mathrm{~nm})$ but biger than NE-PMCA $(29.27 \pm 1.85 \mathrm{~nm})$. Occlucivity of F I NLC-PMCA $(41.50 \pm 4.00 \%)$ higher than SLN-PMCA $(33.52 \pm 3.65 \%)$ and NE-PMCA $(33.52 \pm 3.65 \%)$. PMCA in F I $(60: 40)$ NLC, SLN and NE has the equivalent antiinflammatory activity based on the observations of the PMN cells number in ear skin mice with edema. Conclusion: The NLC-PMCA with the combination of beeswax-oleum cacao and VCO of 60:40 was the best formula.
\end{abstract}

KEYWORDS: anti-inflammatory activity, beeswax, nanostructured lipid carrier (NLC), oleum cacao, $p$ methoxycinnamic acid (PMCA), virgin coconut oil (VCO).

\section{INTRODUCTION:}

In a previous study $p$-methoxycinnamic acid (PMCA), which is difficult to dissolve in water, was formulated in the nanoemulsion [1]. It was known the first colloidal system based on nanotechnology that successfully carries active ingredients through the skin barrier for topical use is the nanoemulsion system [2,3]. The PMCA nanoemulsion system using a combination of surfactants (Tween 80 and Span 80 ), ethanol $96 \%$ cosurfactant, and several plant oil phases, namely VCO, corn oil, and soybean oil [3].

\footnotetext{
Received on 21.02.2019

Modified on 11.03.2019

Accepted on 06.04.2019

C RJPT All right reserved

Research J. Pharm. and Tech 2019; 12(8): 3619-3625.

DOI: $10.5958 / 0974-360 X .2019 .00617 .6$
}

From the study, it was determined that PMCA nanoemulsion that uses VCO as an oil phase produces the smallest droplet size. This is because VCO contains fatty 5 cids with $\mathrm{C}$ atomic chains, which are shorter than the fatty acid content in corn oil and soybean oil. The smaller $14 \mathrm{e}$ of nanoemulsion droplets results in the greater rate of release of drug il15 edients from the carrier system and the rate of penetration of drug ingredients into the skin, so the resulting effectiveness is also higher. However, being in storage for more than 2 months, PMCA nanoemulsion preparations tend to coalescence, so the size of the nanoemulsion droplets grows larger [4]. Than the PMCA formulated in Solid Lipid Nanostructure (SLN) systems, the liquid lipid is replaced with solid lipid using cetylalcohol and Tween 80 as surfactant can inhibit release and extend their anti- 
inflammatory effects [5] However, the use of solid lipids that are too ordered on the storage the active 13 redients tends to be pushed out, so a combination of solid lipids and liquid lipids is needed to overcome this. The improv $12 \mathrm{ent}$ of the SLN system is the NLC system, which consists of a certain amount o 3 solid lipid and liquid lipid matrices. NLC remains in its solid form by controlling the levels of liquid lipids added to the formulation, so the controlled drug release properties for NLC can be achieved [6]. Liquid lipids in NCL can reduce crystalline formation in solid lipids thus increasing system stability on storage $[7,8]$. Various liquid oils and solid lipids can be used as NLC components, among others for example combination of olive oil and palmitic acid (1.8:4.8) as NLC system to deliver ubiquinone (Q10) as an antiaging [9].

In this research the NCL system as PMCA carrier used $\mathrm{VCO}$ as liquid lipid combined with combinations of oleum cacao and beeswax as solid lipid in various ratios and Tween 80 and Span 80 as stabilizer. Furthermore, in the NLC-PMCA system formed characterization and in vivo effectiveness tests are carried out.

11

\section{MATERIALS AND METHODS:}

\section{Materials:}

The materials used in the study which unless otherwise stated have pharmaceu 7 al grade purity are pmethoxycinnamic acid (Sigma Aldrich), Tween 80 (Sigma Aldrich), Span 80 (Sigma Aldrich), VCO (UD. Cocos Coconut), beeswax (PT. Kurniajaya Muktisentosa), oleum cacao (Coffee and Cacao Research Center, Jember-Indonesia), Popylen glycol (PT. Brataco), Sodium benzoate (PT. Brataco), Ethanol $96 \%$ p.a (E Merck), Na acetate p.a. (E Merck), and Acetic acid p.a. (E Merck)

\section{Sample preparation:}

NLC-PMCA system with different ratios of oleum cacao-beeswax as solid lipids and VCO as liquid lipids, namely F I (60:40), F II (70:30), and FIII (80:20) and SLN-PMCA as shown in Table 1, were prepared using high shear hot homogenization method by Ultra-Turrax High Shear Homogenizer IKA T-25. The NLC-APMS system is made by melting beeswax at $70{ }^{\circ} \mathrm{C}$. After beeswax melts, add oleum cacao to beeswax and let the oleum cacao melt. The APMS which has been dissolved in VCO added into the mixture of beeswaxoleum cacao. And Tween 80 and Span 80 heated at 70 ${ }^{\circ} \mathrm{C}$ mixed with the lipid phase. At the same time sodium benzoate, propylenglycol and phosphate buffer $\mathrm{pH} 4.2 \pm$ 0.02 were heated at $70^{\circ} \mathrm{C}$ as water phase. Then the water phase is slowly dispersed into the lipid phase which is stirred with Ultra-Thurax High Shear Homogenizer at a speed of $5000 \mathrm{rpm}$ until all phases of water are exhausted then continued by adding stirring speed to $16,000 \mathrm{rpm}$ for 2 minutes. The next process is the cooling process, which is carried out with a speed decrease at $500 \mathrm{rpm}$ stirred using a magnetic stirrer to reach room temperature $\left(25^{\circ} \mathrm{C}\right)$. For NE-PMCA preparation, all components were mix by magnetic stirrer at room temperature, $500 \mathrm{rpm}, 5$ minutes, than increase mixing speed to $1000 \mathrm{rpm}, 10$ minutes.

\section{Sample characterization:}

Characterization of the sample includes: 1) the $\mathrm{pH}$ value inspection using $\mathrm{pH}$-meter, 2) viscosity measurement using a cone and plate viscometer, 3) particle size measurement and 11 lidispersity index using Delsa ${ }^{\mathrm{TM}}$ Nano Submicron Particle Size and Zeta Potential Dynamic Light Scattering, 4) and the melting temperature using Differential Scanning Calorimeter (DSC).

\section{Entrapment efficiency (\%EE):}

Measurements of percent entrapment efficiency (EE) were carried out by diluting $100 \mathrm{mg}$ NLC with acetate buffer $\mathrm{pH} 4.20 \pm 0.2$ then centrifuged $2500 \mathrm{rpm}$ for \pm 45 minutes and filtered using filter paper. The supernatant was pipetted $2.0 \mathrm{ml}$ and added acetate buffer $\mathrm{pH} 4.20 \pm$ 0.2 to $10.0 \mathrm{ml}$ in the measuring flask. The solution was filtered again using Whatman Millipore filter paper 0.22 $\mu \mathrm{m}$. Then the solution was measured at the maximum wavelength of the PMCA which is then compared with the absorption of standard solutions. The data obtained is the concentration of PMCA in the NLC water phase. The calculation of \% EE (percentage of entrapment efficiency) used the following equation (1).

Table 1 Material Composition in NLC-PMCA, SLN-PMCA and NE-PMCA

\begin{tabular}{|c|c|c|c|c|c|}
\hline \multirow{2}{*}{$\begin{array}{l}\text { Name } \\
\text { Materials }\end{array}$} & \multicolumn{5}{|c|}{ Formula Concentration $(\% \mathrm{~b} / \mathbf{v})$} \\
\hline & F I $(60: 40)$ & F II (70:30) & F III (80:20) & SLN & NE \\
\hline PMCA & 0.20 & 0.20 & 0.20 & 0.20 & 0.20 \\
\hline Oleum Cacao & 2.97 & 3.46 & 3.96 & 4.95 & - \\
\hline $\mathrm{VCO}$ & 2.64 & 1.98 & 1.32 & - & 2.66 \\
\hline Tween 80 & 5.74 & 5.84 & 5.94 & 4.39 & 18.66 \\
\hline Span 80 & 14.76 & 14.66 & 14.56 & 16.11 & 1.92 \\
\hline Buffer Acetate $\mathrm{pH} 4.2 \pm 0.2$ & Ad 100 & Ad 100 & Ad 100 & Ad 100 & Ad 100 \\
\hline
\end{tabular}


$\mathrm{EE}(\%)=\frac{\mathrm{W}_{\text {initial }} \text { drug }-\mathrm{W} \text { free durg }}{\mathrm{W}_{\text {initial }} \text { drug }} \times 100 \%$------ (1)

Notes:

$\mathrm{W}_{\text {initial drug: }}$ The amount of active ingredients used

$\mathrm{W}_{\text {free drug: }}$ The amount of free active ingredients that are in the water phase

Furthermore, the average, SD, and CV calculation were calculated from the efficiency of PMCA entrapment in the NLC system [7].

\section{Oclusivity test:}

The occlusivity test was carried out by in vitro method. Amaout of $5 \mathrm{ml}$ water was puted into each vial $(10 \mathrm{ml})$ with the same diameter. Previously, the empty and dry vials and the vial that filled with water were weighed. The vial that filled with water were caped using a membrane filter (cellulose filter, with $0.45 \mathrm{~mm}$ pore, Whatman no. 4), and than tie with a rope and make sure there is no gap between water and membrane. Then put 10 drops of Isopropyl myristate to saturate the membrane and leave it overnight. Sample (0.05 grams) was applied evenly to the membrane then observed for a week. After a week, the water that has been lost were calculate using the following equetion (2) [10]:

$$
\mathrm{F}=\frac{\mathrm{B}}{\mathrm{A}} \times 100 \%
$$

Notes:

$\mathrm{A}=$ Amount of water lost in control

$\mathrm{B}=$ Amount of water lost in the sample

\section{Anti-inflammation effectiveness test:}

The effectiveness test of PMCA in the NLC system uses mice as experimental animals. Measuring the ability to reduce the thickness of the ear skin of mice with edema and the number of polymorpho nuclear (PMN) cells, there were 5 animal treatment groups namely; positive control group, negative control group, group with NLCPMCA treatment, group with SLN-PMCA treatment, and group with NE-PMCA treatment. PMCA effectiveness test was carried out on the skin of mice ears which had been induced inflammation by croton oil $(2.5 \%$ in acetone) for as much as $10 \mu \mathrm{l}$ using micropipette. One hour after being dripped with test samples. Then, 9 hours after treatment, the histological preparations of mice ear were made after the mice were sacrificed and then stained with Hemato-Eosin (HE). The histological preparations were then observed under a microscope. Measurements were made on (edema) skin thickness and the amount of inflammatory cell infiltration of polymorpho nuclear (PMN) or neutrophils, namely the main inflammatory cells in acute inflammation [4]. Percentage reduction in edema thickness (PTE) was calculated based on the equation(3):

$$
\% \mathrm{PTE}=\frac{T(K+)-T(S)}{T(K+)-T(K-)}
$$

Notes:

$\%$ PTE $=$ percent of skin thickness decrease

$\mathrm{T}(\mathrm{K}+)=$ thickness of skin that had edema (positive control)

$\mathrm{T}(\mathrm{S})=$ thickness skin that had edema after sample was applied

$\mathrm{T}(\mathrm{K}-)=$ thickness of healthy skin (negative control)

The calculation of PMN cells on histological preparations of mice without treatment (K-), after induction of croton oil $(\mathrm{K}+)$, after treatment with NLCPMCA (NLC), after treatment with SLN-PMCA (SLN), and after treatment with nanoemulsion PMCA (NE) were observed using an Olympus CX21 microscope at 400x magnification.

\section{RESULTS:}

\section{The $\mathrm{pH}$ Value and Viscosity:}

The measurement results of the $\mathrm{pH}$ value and viscosity of the NLC-PMCA system with various ratios of solid lipid combination of beeswax-oleum cacao with $\mathrm{VCO}$ as liquid lipid, namely FI (60:40); F II (70:30); F III (80:20); SLN-PMCA and NE-PMC 4 by pH-meter and the cone and plate viscometer can be seen in Table 2 . Based on the data $\mathrm{pH}$ in Table 2 all of the formula has $\mathrm{pH} 10$ und 4 , and the results of the viscosity statistical test using one-way ANOVA with $95 \%$ confidence level, obtained results a significance value of 0.002 smaller than 0.05 and the results of the Tukey's HSD test, it can be concluded that NE-PMCA has the lowest viscosity, and for the NLC-PMCA the F I $(60: 40)$ has the lowest viscosity.

\section{Particle Size and Particle Size Distribution:}

Particle size measurement results of the NLC-PMCA system with various ratios of beeswax-oleum cacao as solid lipid with VCO as liquid lipid, namely: FI (60:40); F II (70:30); F III (80:20), SLN-PMCA and NE-PMCA using the Delsa ${ }^{\mathrm{TM}}$ Nano Submicron Particle Size and Zeta Potential Dynamic Light Scattering can be seen in Table 3 . The results of particle size examination were then subjected to a one-way ANOVA statistical test with $95 \%$ confidence degree and Tukey's HSD test. A significance value of 0.239 was obtained, which was more than 0.05 . This means that there was no differences in particle size for all NLC-PMCA formulas. And the particle size distribution or polydispersity index (PI) measurement results of all systems were below 0.3, its mean the particle size each formula homogen. 
Table 2: $\mathrm{pH}$ value and viscisity of NLC-PMCA System with Various ratios of Beeswax-Oleum Cacao as Solid Lipid with VCO as Liquid Lipid, Namely: FI (60:40); F II (70:30); and F III (80:20); SLN and NE

\begin{tabular}{|l|l|l|l|l|}
\hline \multirow{2}{*}{ Formula } & pH value & \multicolumn{2}{|l|}{ Viscosity (cps) } \\
\cline { 2 - 5 } & Average & SD & Average & SD \\
\hline F I (60:40) & 4.47 & 0.18 & 126.90 & 17.34 \\
\hline F II $(70: 30)$ & 4.51 & 0.21 & 163.10 & 01.81 \\
\hline F III (80:20) & 4.36 & 0.01 & 189.83 & 10.96 \\
\hline SLN & 4.48 & 0.07 & 425.57 & 6.43 \\
\hline NE & 4.01 & 0.06 & 6.13 & 0.08 \\
\hline
\end{tabular}

Table 3: Particle/Droplet Sizes and Polydispersity Index (PI) of NLC-PMCA System with Various Ratios of Beeswax-Oleum Cacao as Solid Lipid with VCO as Liquid Lipid, Namely: FI (60:40); F II (70:30); and F III (80:20), NE-APMS and SLN-APMS

\begin{tabular}{|l|l|l|l|l|}
\hline \multirow{2}{*}{ Formula } & \multicolumn{2}{|l|}{ Particle size (nm) } & \multicolumn{2}{l|}{$\begin{array}{l}\text { Polidispersity Index } \\
\text { (PI) }\end{array}$} \\
\cline { 2 - 5 } & Average & SD & Average & SD \\
\hline F I (60:40) & 236.00 & 17.15 & 0.242 & 0.031 \\
\hline F II $(70: 30)$ & 241.01 & 13.72 & 0.228 & 0.001 \\
\hline F III (80:20) & 255.08 & 06.10 & 0.237 & 0.046 \\
\hline SLN & 665.60 & 72.59 & 0.461 & 0.060 \\
\hline NE & 29.27 & 1.85 & 0.435 & 0.020 \\
\hline
\end{tabular}

\section{Melting Point and Recrystallization Index:}

The mesurement of the melting point and recrystallization index was carried out on the NLCPMCA system with various ratios of beeswax-oleum cacao as solid lipid with VCO as liquid lipid, namely: FI (60:40); F II (70:30); and F III (80:20) using Differential Scanning Calorimeter (DSC) compared to oleum cacao, beeswax, and PMCA. The results of the thermogram melting point of the formulas can be seen in Figures 1,2 and 3 , while the melting point parameters of each formula can be seen in Table 4. From the peaks that appear in the thermogram of each sample, the recrystallization index was calculated based on the following equation (4):

$$
\triangle \mathrm{H} \text { NLC }
$$

$\% \mathrm{RI}=$

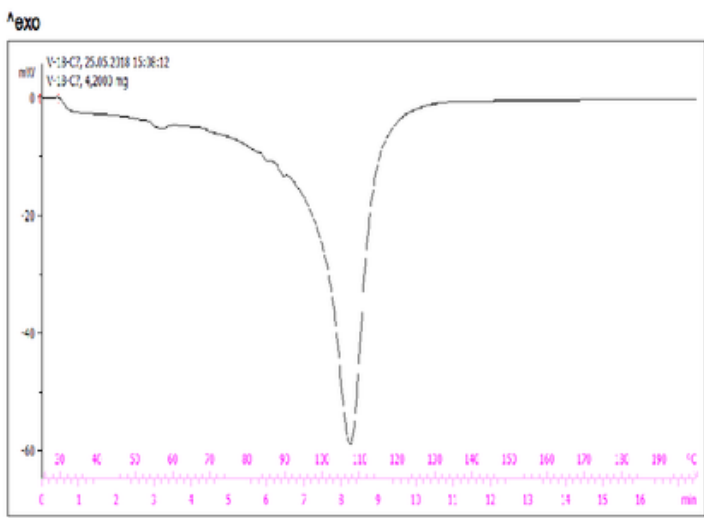

Lab: METTLER

STAR SW 11.00

Figure 1: Thermogram of melting temperature of NLC-PMCA formula I (60:40)

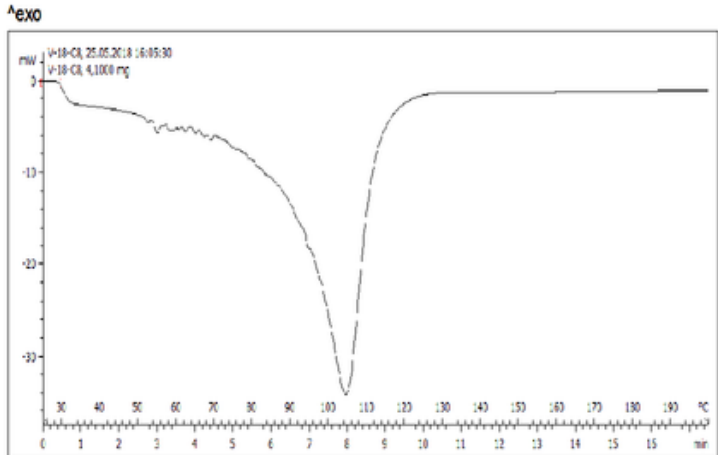

Lab: METTLER

STAR SW 11.00

Figure 2: Thermogram of melting temperature of NLC-PMCA formula II (70:30)

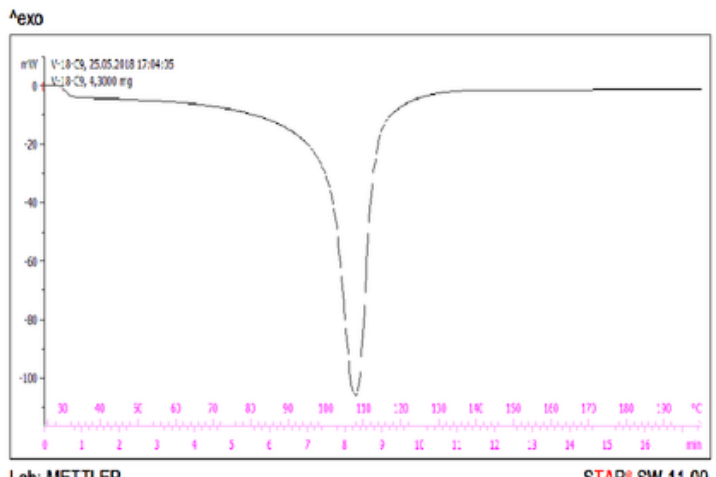

Lab: METTLER

STAR SW 11.00

Figure 3: Thermogram of melting temperature of NLC-PMCA formula III (80:20)

Table 4: Melting Points of PMCA, Oleum Cacao, Beeswax, and NLC-PMCA

\begin{tabular}{|l|l|l|l|}
\hline Materials & $\begin{array}{l}\text { Melting point } \\
\left({ }^{\circ} \mathrm{C}\right)\end{array}$ & $\mathbf{\Delta H}(\mathbf{J} / \mathbf{g})$ & RI (\%) \\
\hline PMCA & 173.00 & -110.27 & - \\
\hline Beeswax & 59.99 & -300.46 & - \\
\hline Oleum Cacao & 33.65 & -115.17 & - \\
\hline Formula I (60:40) & 56.85 & -5.37 & 0.326 \\
\cline { 2 - 3 } & 105.52 & -698.97 & \multirow{2}{*}{0.074} \\
\hline Formula II (70:30) & 55.01 & -1.43 & \\
\cline { 2 - 3 } & 103.44 & -722.52 & \multirow{2}{|l}{} \\
\hline Formula III (80:20) & 104.13 & 1421.84 & - \\
\hline
\end{tabular}

\section{Entrapment Efficiency:}

The results of the determination of PMCA recovery in the NLC, SLN system with different ratios of solid lipids and liquid lipids can be seen in Table 5, it was known that the percentage of recovery of all formulas were $>94 \%$, and the results of the calculation of the $\%$ $\mathrm{CV}$ value of active materials showed that the \% CV value of all formulas were less than $6 \%$, so it can be said that all NLC-PMCA formulas were homogeneous.

The determination of the PMCA in $N 1 \mathrm{C}$ and SLN system entrapment efficiency, the results can be seen in 
Table 5. Meanwhile, the results of the one-way ANOVA statistical test with $95 \%$ confidence degree followed by the Tukey's HSD test with a significance value of 0.020 $<0.05$. Thus, it can conclude that F I $(60: 40)$ had a higher entrapment efficiency than F II (70:30) and F III $(80: 20)$.

\section{Occlusivity test:}

The result of F1 NLC-PMCA $(41.50 \pm 4.00 \%)$, SLNPMCA $(33.52 \pm 3.65 \%)$ and NE-PMCA $(20.30 \pm 2.39$ $\%$ ) occlusivites after one week obsevation known the F1 NLC-PMCA system has higer occlusivity.

\section{Anti-inflammation effectiveness test:}

To determine the PMCA activity in the NLC system, a test was conducted on the reduction in skin thickness that induced edema in the ear skin tissue of the mice, as well as the observation of the number of PMN cells. The NLC-PMCA formula tested for activity was F $1(60: 40)$ because it had the highest entrapment efficiency. The NLC-PMCA activity test was compared with nanoemulsion system (NE-PMCA) and solid lipid nanoparticle system (SLN-PMCA).

\section{a. Decrease of Skin Thickness at The Ears Mice with Edema:}

The results of the PMCA activity test in the NLC system on the 1 hickness reduction of the ear mice skin with edema can be seen in Table 6 and Figure 4. The results of a one-way ANOVA statistical test with $95 \%$ confidence degree and Tukey's HSD test on the reduction in the thickness of the skin with edema in the ear skin tissue of mice observed in 5 visual fields with a magnification of $100 \mathrm{x}$, which found a significance value of $0.623>$ from 0.05 . Skin thickness of mouse ears after exposure with NLC-PMCA, SLN-PMCA and NEPMCA were not significantly different from the negative control and significantly different from the positive controls. So it can be concluded that NLC-PMCA can provide the same anti-inflammatory activities as SLNPMCA and NE-PMCA.

\section{b. Number of PMN Cells:}

The results of the calculation of the number of PMN cells contained in histology preparations in 5 visual fields with magnifications of $400 x$ can be seen in Table 6 and Figure5. It was known that NLC-PMCA can reduce the number of PMN cells in the ear mice skin with edema better than SLN-PMCA and nanoemulsiPMCA, but still far compared to the negative control.
Table 5: Recovery Percentage and Entrapment Efficiency of PMCA in NLC and SLN

\begin{tabular}{|l|l|l|l|l|l|}
\hline \multirow{2}{*}{ Formula } & \multicolumn{2}{|l|}{ Recovery (\%) } & \multicolumn{2}{l|}{$\begin{array}{l}\text { Entrapment } \\
\text { efficiency (\%) }\end{array}$} \\
\cline { 2 - 6 } & Average & SD & $\begin{array}{l}\text { CV } \\
(\%)\end{array}$ & Average & SD \\
\hline F I (60:40) & 94.37 & 0.175 & 0.19 & 43.37 & 1.10 \\
\hline F II (70:30) & 94.70 & 0 & 0 & 33.99 & 1.76 \\
\hline F III (80:20) & 94.39 & 1.09 & 1.16 & 27.80 & 8.02 \\
\hline SLN & 93.76 & 3.72 & 3.95 & 34.46 & 2.85 \\
\hline
\end{tabular}

Table 6: The Ear Mice Skin Thickness after 9 Hours Treatment and The Number of PMN Cells in Histological Preparations of Mice Ear Skin Treated with NLC-PMCA, SLN-PMCA, and NEPMCA Compared to Positive Control and Negative Control. Observation Using Olympus CX21 Microscope, With 100x and 400x Magnifications

\begin{tabular}{|l|l|l|}
\hline Treatment & $\begin{array}{l}\text { Skin thickness } \\
\text { per 5 field of } \\
\text { view average } \pm \\
\text { SD }(\boldsymbol{\mu m})\end{array}$ & $\begin{array}{l}\text { Number of PMN Cells } \\
\text { per 5 field of view } \\
\text { average } \pm \text { SD }(\%)\end{array}$ \\
\hline Positive control & $3354.4 \pm 364.2$ & $166.6 \pm 23.3$ \\
\hline Negative control & $1390.6 \pm 408.6$ & $5.6 \pm 0.7$ \\
\hline NLC PMCA & $1834.9 \pm 355.4$ & $85.6 \pm 25.1$ \\
\hline SLN PMCA & $2177.5 \pm 346.4$ & $93.3 \pm 17.2$ \\
\hline NE PMCA & $1862.0 \pm 136.9$ & $115.3 \pm 43.5$ \\
\hline
\end{tabular}

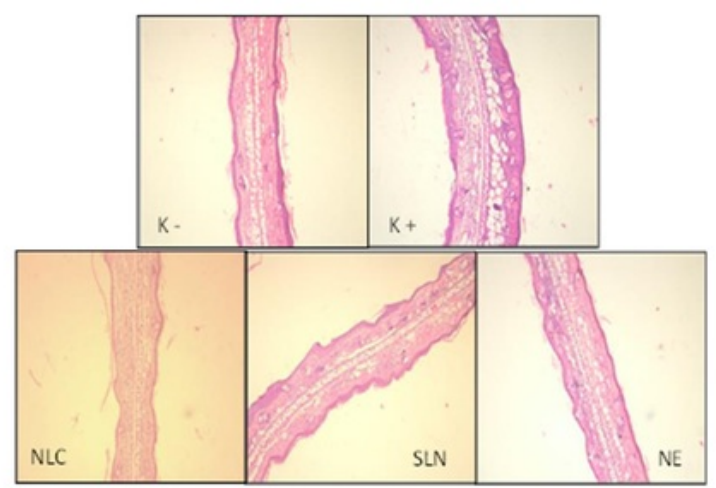

Figure 4: Histology of ear skin thickness of mice in negative control (K-), positive control $(\mathrm{K}+)$, with NLC-PMCA (NLC) treatment, with SLN-PMCA (SLN) treatment, ...and with nanoemulsion-PMCA (NE).. treatment. Observed using Olympus CX21 microscope with 100x magnification

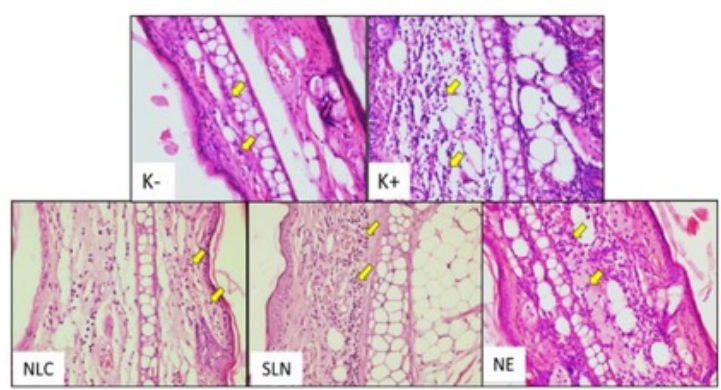

Figure 5: PMN cells in the ears of mice without treatment (K-), after induced by croton oil $(\mathrm{K}+)$, after treatment with NLCPMCA (NLC), after treatment with SLN-PMCA (SLN), and after treatment with nanoemulsion PMCA (NE) Observed with Olympus CX21 microscope at 400x magnification 


\section{DISCUSSION:}

In this NLC-PMCA study VCO was used as liquid lipid because it was determined that PMCA nanoemulsion that uses VCO as an oil phase produces the smallest droplet size. This is caused by VCO contains fatty $5 \mathrm{ds}$ with $\mathrm{C}$ atomic chains which are shorter than the fatty acid content in corn oil and soybean oil. The smal $8 \mathrm{r}$ size of nanoemulsion droplets results in the greater release rate of active ingredients from the carrier system and the penetration rate of active ingredients into the skin, so the resulting effectiveness is also higher [4]. As stabilizers, Tween 80 and Span 80 were used, which are nonionic surfactants, safer than other types of surfactant $3 \mathrm{n}$ the event of skin irritation $[11,12]$. NLC remains in its solid form by controlling the levels of liquid lipids added to the formulation, its can controlled drug release properties for NLC can be achieved. ${ }^{6}$ The choice of constituent materials and ratios between solid lipids and liquid lipids are important factors in the NLC formulation. To decreased orderness of the solid lipid in this research also used combination of beeswax and oleum cacao.

The data $\mathrm{pH}$ value in Table 2 it is known that all NLCPMCA systems that formed had $\mathrm{pH}$ values that are slightly below the $\mathrm{pH}$ range of the skin at $4.5-6.5$ so it does not causes irritation. From the viscosity data, it is known that F I (60:40) has the lowest viscosity, F I has the highest VCO content, which is the highest liquid lipid. An increase in liquid lipid consetration decreases the viscosity of NLQg PMS, but has no effect on particle size and particle size distribution or polydispersity index (PI). All formula have particle size $<500 \mathrm{~nm}$, it was known a good NLC system has particle size up to $500 \mathrm{~nm}$ [7]. And then in Table 3, the results of particle size distribution or polydispersity index (PI) of NLC-PMCA systems were below 0.5 indicated the absence of particle aggregation, and the presence of a homogeneous particle size distribution. [13,14].

Based on the results of the melting point examination with DSC in Figures 1, 2, 3 and Table 4 it can be seen that the F III has a different thermogram form than F I and F II. In F III there is only one peak, this can be caused by the decreasing amount of liquid lipids the possibility of molecular interaction between oleum cacao and beeswax would occur, so there was endothermic peak of each solid lipid (oleum cacao and beeswax) an appeared. In F I and F II, there was a shift in endothermic (oleum cacao and beeswax) peaks (56.85 ${ }^{\circ} \mathrm{C}$ and $55.01^{\circ} \mathrm{C}$ ) and a decrease in enthalpy between single solid lipids with NLC-PMCA $(5.87 \mathrm{~J} / \mathrm{g}$ and 1.43 $\mathrm{J} / \mathrm{g}$ ). This can be due to differences in composition between single solid lipids (oleum cacao and beeswax) in the formulas. In the calculation of the recrystallization index for F I and F II, a decrease in the value of RI
$(0.326$ and $0.074 \%)$ was obtained. This shows a decrease in the order of the crystal lattice. From these results, it can be concluded that the addition of PMCA and $\mathrm{VCO}$ can affect endothermic conditions (melting point and enthalpy).

The entrapment efficiency of F I higer than F II and F III its caused by the use of a combination of solid lipids and liquid lipids in NLC system can reduce crystallinity in the crystalline matrix and form irregular matrix, thus creating a space where drug molecules can be entrapped in the system $[15,16]$. Higher content of liquid lipid in NLC-PMCA also occured the less ordered matrices, supported by the recrystallization index data. The lower of recrystallization index of an ingredient occered the less ordered the crystal lattice is, the crystal space can accommodate larger drugs, so the resulting entrapment efficiency would be greater.[17,18]. The addition of liquid lipids also increased stability caused the crystallization process to be inhibited, so drug expulsion during storage can be minimized [17,19]. NLC-PMCA can produce anti-inflammatory activity equivalent to SLN-PMCA and NE-PMCA

To seek improvement in the delivery system so as to increase the effectiveness of the PMCA as an antiinflammatory, the rate of release and penetration of the system needs to be determined. An active material can have the desired effect if it can be released from the system, and then penetrate into the skin to the site of action. Easier the active material detaches from the system, the faster penetration will be and the faster effect will be too.

\section{CONCLUSIONS:}

Based on the results of the characterization of the NLC PMCA system with ratios of beeswax-oleum cacao solid lipid and VCO lipid of 60:40, 70:30, and 80:20 which included organoleptic, $\mathrm{pH}$, viscosity, particle size, particle size distribution, melting point, entrapment efficiency, and activity tests, in this research it can be concluded that: The increase of the amount of VCO in the NLC-PMCA system results in smaller particle size, lower viscosity, and greater entrapment efficiency, namely in the combination of beeswax-oleum cacao solid lipid and VCO liquid lipid of 60:40. NLC-PMCA with a combination of beeswax-oleum cacao solid lipid and VCO liquid lipid of 60:40 had equivalent antiinflammatory activity as SLN-PMCA and nanoemulsiPMCA, based on the observations of the PMN cells number in ear skin of mice with edema. The NLCPMCA with the combination of beeswax-oleum cacao and VCO of 60:40 was the best formula. 


\section{ACKNOWLEDGEMENTS:}

The authors would like to thank the Minister of Research, Technology 2 and Higher Education who funded this research, Universitas Airlangga and the Faculty of Pharmacy for providing laboratory facilities for the studies, and to students Alifiah Sakinah and Sarah Nurul Iman, under the writers' supervision who helped conduct this research.

\section{THICAL CLEARENCE:}

All animal experiments were conducted with the permission from Animal Care and Use Committee (ACUC) of Veterinary Faculty, Airlangga University, Surabaya-Indonesia. (Reference number; 2.KE.051.01, 2018).

\section{CONFLICT OF INTEREST:}

No conflict of interest is associated with this work.

\section{AUTHOR CONTRIBUTION:}

We declare that this work was done by the author(s) named in this article and all liabilities pertaining to claims relating to the content of this article will be borne by the authors.

\section{REFERENCES:}

1. Montenegro, Lucia., Lai, Francesco., Offerta, Alessia., Sarpietro, Maria Grazia., Micicche, Lucia., Maccioni, Anna Maria., Valenti, Donatella., and Fadda, Anna Maria. From Nanoemulsions to Nanostructured Lipid Carriers: A Relevant Development in Dermal Delivery of Drugs and Cosmetics. Journal of Drug Delivery Science and Technology, 2016,32,100-112

2. Sharma, Shurbi, and Sarangdevot, Kumkum. Nanoemulsions for Cosmetics. International Journal of Advanced Research in Pharmaceutical and Bio Sciences, 2012, 2(3), 408-415

3. Erawati T, Hendradi E, Soeratri W. Praformulation study of pmethoxycinnamic acid (PMCA) nanoemulsion using vegetable oils (soybean oil, com oil, VCO), Int J Pharm Pharm Sci, 2014, 6(2), 99-101

4. Erawati TM, Martodihardjo S, Soeratri W. Effect of different types and amount of lipid acid content on com oil and virgin coconut oil (VCO) on the characteristic, release rate, penetration and effectiveness of para methoxycinnamic (PMCA) in nanoemulsion. Proceedings The $4^{\text {th }}$ Current Drug Development Intemational Conference, June 1-3, Phuket, Thailand, Published by Faculty of Pharmaceutical Sciences, Prince of Songkla Univercity. 2016, ISBN 978-616-271-303-3, 225 - 228.

5. Noorma Rosita, Widji Soeratri, Tristiana Erawati, Ayunanda, Wakhida Fitriyani In vitro effectivity para methoxy cinnamate acid (PMCA) in solid lipid nanostructure (SLN) system using cetylalcohol as lipid formulated in HPC-H gel base, World Journal of Pharmaceutical Research. 2014, Vol. 3, Issue 5, 58-65

6. Puglia C, Blassi P, Rizza L, Scoubben A, Bonina F, Rossi C, and Ricci M. Lipid nanoparticles for prolonged topical delivery: An in vitro and in vivo investigation, International Joumal Pharmaceutical. 2008. 357, $295-304$

7. Phatak A, and Chaudhari P. Development and evaluation of nanostructured lipid carrier (NLC) based topical delivery of an antiinflammatory drug, Journal of Pharmaceutical Respiration. 2013. 7(8), 677-685

8. Zauner W, Farrow NA, Haines AM. In vitro uptake of polstyrene microspheres: Effect of particle size cell line and cell density, Journal of Control Release. 2001. 70, 39-51Fenita Shoviantari,
Tristiana Erawati, Widji Soeratri. Skin penetration of coenzyme Q10 in nanostructure lipid carriers using olive oil and cetylpalmitate, Int. J. Pharm. and Clin. Research, 2017; 9(2): 142145

9. De Vringer, T, Yamanouchi Europe BV, Topical preparation containing a suspension of solid lipid particle. U.S. Patent 5,667,800. 1997.

10. Santos P, Watkinson AC, Hadgraft J, Lane ME (2008) Application of microemulsion in dermal and transdermal drug delivery, Skin Pharmacol Physiol. 2008, 21, 248, 250.

11. Kumar, B., Jain, S. K., Prajapati, S.K., Mahor, and Kumar, A. Development and Characterization of Transdermal Microemulsion Gel for an Antiviral Drug. International Journal of Pharmaceutical Science and Research. 2010, 57-73

12. Wei Keat Ng, Yazan LS, Yap LH, Nor Hafiza WAG, How CW, Abdullah R. Thymoquinone-loaded nanostructured lipid carrier exhibited cytotoxicity towards breast cancer cell lines (MDA-MB231 and MCF-7) and cervical cancer cell lines (HeLa and $\mathrm{SiHa}$ ). BioMed Research Intemational. Hindawi Publishing Corporation, Article ID 263131, Vol 2015, 1-10

13. Das $\mathrm{S}$ and Chaudhury $\mathrm{A}$, Recent advances in lipid nanoparticle formulations with solid matrix for oral drug delivery, AAPS PharmSciTech, 2011, Vol. 12, 62-76.

14. Attama AA, Schicke BC, Müller-Goymann CC further characterization of theobroma oil-beeswax admixtures as lipid matrices for improved drug delivery systems. European Joumal of Pharmaceutics and Biopharmaceutics, 2006, 64(3), 294-306

15. Attama AA, Schicke BC, Paepenmuller T, Müller-Goymann CC Solid lipid nano-dispersions containing mixed lipid core and a polar heterolipid: characterization. European Journal of Pharmaceutics and Biopharmaceutics. 2007, Vol. 67, 48-57.

16. Hu F, Jiang S, Du Y, Yuan H, Ye Y, and Zeng S, Preparation and characteristics of monostearin nanostructured lipid carriers. International Joumal of Pharmaceutics, 2007, Vol. 314, p. 83-89.

17. Souto EB, Müller RH, SLN and NLC for topical delivery of ketoconazole, Joumal of Microencapsulation; 2007, Vol. 5 No. 22, p. $501-510$

18. Muller RH, Radtke M, Wissing SA, Nanostructured lipid matrices for improved microencapsulation of drugs, International Joumal of Pharmaceutics, 2007, Vol. 242, p. 121-128 
The Anti-inflammatory Activity of p-methoxycinnamic acid (PMCA) in the Nanostructured lipid carrier (NLC) system using combinations of solid lipid, beeswax-oleum cacao and liquid lipid, Virgin Coconut

ORIGINALITY REPORT

6

SIMILARITY INDEX
$6 \%$

INTERNET SOURCES
$4 \%$

PUBLICATIONS
$0 \%$

STUDENT PAPERS

PRIMARY SOURCES

1 forddele.dk

Internet Source

2 www.ajol.info Internet Source

Han, F.. "Effect of surfactants on the formation and characterization of a new type of colloidal drug delivery system: Nanostructured lipid carriers", Colloids and Surfaces A:

Physicochemical and Engineering Aspects, 20080215

Publication

4 repository.unimal.ac.id Internet Source

5 repository.unair.ac.id Internet Source 
7 media.neliti.com

8 www.mdpi.com

Internet Source

9 akademiai.com

Internet Source

10 idea.library.drexel.edu

11 www.dovepress.com

12 Atul Anand Phatak, Praveen Digambar

Chaudhari. "Development and evaluation of

Nanostructured Lipid Carrier (NLC) based

topical delivery of an anti-inflammatory drug",

Journal of Pharmacy Research, 2013

Publication

13 Pardeike, J.. "Lipid nanoparticles (SLN, NLC) in cosmetic and pharmaceutical dermal products", International Journal of Pharmaceutics,

20090121

Publication

14 www.tandfonline.com Internet Source

"Percutaneous Penetration Enhancers Chemical Methods in Penetration Enhancement", Springer 
Nature, 2016

Publication

$\begin{array}{llll}\text { Exclude quotes } & \text { Off } & \text { Exclude matches } & \text { Off } \\ \text { Exclude bibliography } & \text { On } & \end{array}$

